\title{
The Preterm Effect of Antiretroviral Drugs on Total Lymphocyte Cells and CD4 Cells in HIV-Infected Pregnant Women
}

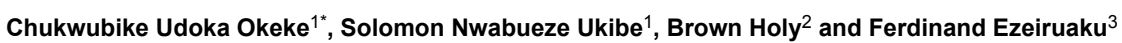 \\ ${ }^{1}$ Department of Prosthetics and Orthotics, School of Health Technology, Federal University of Technology, Owerri, Imo State, Nigeria \\ ${ }^{2}$ Department of Medical Laboratory Science, Faculty of Sciences, Rivers State University of Science and Technology, Port Harcourt, Nigeria \\ ${ }^{3}$ Department of Medical Laboratory Science, Faculty of Basic Medical Sciences, Niger Delta University, Bayelsa State, Nigeria
}

"Corresponding author: Okeke Chukwubike Udoka, Department of Prosthetics and Orthotics, School of Health Technology, Federal University of Technology, Owerri, Imo State, Nigeria, Tel: +2348037353551; E-mail: jmdsph@yahoo.com

Received date: Apr 06, 2016, Accepted date: May 12, 2016, Publication date: May 16, 2016

Copyright: (C) 2016 Okeke CU, et al. This is an open-access article distributed under the terms of the Creative Commons Attribution License, which permits unrestricted use, distribution, and reproduction in any medium, provided the original author and source are credited.

\begin{abstract}
Background: HIV infected pregnant women are placed on antiretroviral drugs for treatment and to avoid maternal to child transmission of HIV. This study was carried out to investigate the effects of the antiretroviral drugs (ARD) on CD4 and Total Lymphocyte cell count (TLC) among these women.

Method: A total of 120 women participated in this study at Bori General Hospital Nigeria. Sixty (60) of them were seropositive to HIV while 60 were seronegative. Blood sample was collected from both groups of women at $2^{\text {nd }}$ and $3^{\text {rd }}$ trimester. The seropositve group was placed on ARD (Nevirapine, Zidovudine) after initial collection of sample at $2^{\text {nd }}$ trimester. CD4 count and TLC were estimated in these samples using Cyflow machine and manual method respectively.
\end{abstract}

Result: CD4 count and TLC were significantly $(p<0.05)$ reduced in HIV infected pregnant women (CD4 count $425.10 \pm 34.0$ cells/uL, TLC $1.97 \pm 0.10 \times 10^{9} / \mathrm{L}$ ) in $2^{\text {nd }}$ trimester than in non- infected group (CD4 count $835.02 \pm$ 36.50 cells/uL, TLC count $2.93 \pm 0.15 \times 10^{9} / \mathrm{L}$ ). The CD4 count significantly rose from $425.10 \pm 34.0$ cells/uL in $2^{\text {nd }}$ trimester to $647.03 \pm 35.77 \mathrm{cells} / \mathrm{uL}$ in $3^{\text {rd }}$ trimester, and TLC significantly rose $(p<0.05)$ from $1.97 \pm 0.10 \times 10^{9} / \mathrm{L}$ in $2^{\text {nd }}$ trimester to $2.26 \pm 0.10 \times 10^{9} / \mathrm{L}$ in $3^{\text {rd }}$ trimester in HIV-infected group. The increase in CD4 cell count $(647.03 \pm$ 35.77 cells/uL) in sero-positive group at $3^{\text {rd }}$ trimester was significantly lower $(p<0.05)$ than that of sero- negative group $\left(948.58 \pm 38.86\right.$ cells/uL). TLC levels in $3^{\text {rd }}$ trimester of both sero-positive group and sero-negative group showed no statistical significant $(p>0.05)$ difference.

Conclusion: Reduction of CD4 cell count and TLC at 2nd trimester in HIV- infected pregnant women showed that HIV infection depleted these immunologic markers in pregnancy. The administration of ARD from second trimester boosted the CD4 cell count and TLC among these infected pregnant women before delivery. Progressive increase in TLC alongside CD4 cell count among the women on ARD suggests that TLC could be used as a surrogate to monitor progress of treatment among HIV-infected pregnant women in resource limited settings.

Keywords: Antiretroviral; HIV; Pregnancy; Total lymphocyte cells; CD4 cells

\section{Introduction}

Antiretroviral drugs (ARD) are medications for the treatment of infections caused by retroviral, primarily Human immunodefficiency virus (HIV). Different classes of antiretroviral drugs act at different stages of the HIV life cycle/parts and they are reverse transcriptase enzyme inhibitors (e.g., zidovudine, lamivudine and Nevirapine), Protease enzyme inhibitors (e.g. lopinavir), fusion of HIV and host cell inhibitors (maraviroc), Integrase enzyme inhibitors (e.g., Bevirimat and Virecom). These drugs can be used singly, but gold standard (combination therapy) for AIDS treatment is advocated to maximize potency, minimize toxicity and diminishes the risk for resistance development by the HIV.

The prevalence rate of HIV infection in pregnant women in African countries is in a worrisome state. Some African countries have HIV prevalence rate of over $30 \%$ in pregnant women [1]. The average HIV prevalence rate among pregnant women in Nigeria is about $4.9 \%$, even, Ikechebelu et al. [2] in their study reported 6\% prevalence in Nnewi, Anambra State. The high prevalence rate in antenatal women among Africans can be attributed to low level of education, grand multipararity, lower income occupation, couples not living together, induced labour, and blood transfusion [2,3].

The HIV infection can adversely affect pregnant women and their fetus directly or indirectly via hormonal alteration. Garcia et al. [4] reported that studies had shown that HIV itself could affect the body's ability to produce and maintain hormone levels. French and Brockletrust [5] stated that pregnancy in HIV infected women might be associated with atleast small increase in risk of adverse maternal outcomes, and these were spontaneous abortion, stillbirth, fetal abnormality, prenatal mortality, low birth weight, preterm delivery etc. Okeke et al. [6] stated that altered estradiol and prolactin levels are hormones implicated in causing these adverse outcomes of pregnancy.

HIV can cause functional abnormalities and quantitative depletion of CD4 T-Lymphocytes in humans. And this can lead to profound 
Page 2 of 4

immunosuppression in HIV infected patients unless the patient has a mutation on CXCR4 and CCR5 chemokine receptors on the CD4 Cells. The dysfunctional effects of HIV on CD4 cells may be as a result of direct infection with HIV or may be caused indirectly by exposure of uninfected cells to various proteins. Indirect effects of HIV infections result in decreased $\mathrm{CD} 4+\mathrm{T}$-cell proliferation and differentiation, dysregulation and decreased production of interleukin-2 (IL-2) and other cytokines, defecting colony formation and other precursor defects. Rich et al. [7] and Wilson et al. [8] stated that there are immune function changes during pregnancy and HIV infection. Bretle et al. [9] stated from their study that in asymptomic HIV infection, changes in the absolute levels of CD4 and CD8 lymphocyte counts are primarily related to changes in other components of the white cell count because there were no changes in $\mathrm{CD} 4 \%$ and CD8\%. By this, they concluded that pregnancy itself has no adverse effect on immunological markers of HIV. Temmerman et al. [10] observed no statistical difference in CD4 and CD8 cells and their ratio between HIV positive and HIV negative women during pregnancy.

There is suggestion that pregnancy hormone; hCG has anti-viral effect on HIV. Simonant et al. [11,12] stated that crude urine from 1st trimester pregnant women had a growth effect on Kaposi's sarcoma, compared with urine from non-pregnant women and men. Lee-Huang et al. [13] observed that anti-viral component of hCG is associated with the beta core fragment of the beta subunit of hCG and are identical to those of human lysozyme and ribonucleases. Bourinbaiar and Lee-Huang [14] reported that hCG has the ability to suppress reverse transcriptase activity in chronically infected lymphocytes and monocytes and likewise it blocks viral transmission resulting from cellcell contact between virus carrying lymphocytes and trophoblasts. Contrariwise, Gross et al. [15] observed an increase in material hCG and viral load, decreased CD4 count among women.

HIV causes functional abnormalities and quantitative depletion of CD4 cells and consequently TLC. Physiological hormonal changes in women during pregnancy do not prevent the effects of HIV on CD4 and TLC. The use of antiretroviral drugs has been established to hamper the proliferation of HIV, and as well enhance the production of CD4 cells and total lymphocyte count in infected humans. This study was carried out to assess the preterm effects of the antiretroviral drugs on the CD4 cells and total lymphocyte count in pregnant women who have physiological changes as a result of hormonal alteration.

\section{Materials and Methods}

A total of 120 pregnant women randomly selected voluntarily participated in this study. Sixty (60) of them who were seronegative to HIV served as control, while the rest 60 who were HIV seropositive started antiretroviral drug treatment at second trimester of pregnancy. Their blood samples were collected at $2^{\text {nd }}$ trimester (before commencement of antiretroviral drugs in seropositive group), and at $3^{\text {rd }}$ trimester before delivery. The samples were put into ethylene diamine tetraacetic acid (EDTA) containers for estimation of CD4 count and TLC.

CD4 count was estimated using cyflow machine, while Total white blood cell count (TWBCC) and percentage lymphocyte count (field staining technique) were estimated using manual method. Total lymphocyte count was calculated from Total white cell count (TWCC) and percentage lymphocyte count), thus;

$$
\text { Total lymphocyte count }(T L C)=\frac{\% \text { lymphocyte count }}{T W C C} \times 100
$$

\section{Statistical analysis}

The data collated were subjected to statistical analysis using MEGASTAT software to determine the mean, standard deviation, standard error of mean (s.e), p-value/level of significance.

\section{Result}

In the Table 1 below, it was observed that there was significant increase $(\mathrm{p}<0.05)$ in CD4 count of sero-negative pregnant women from $835.02 \pm 36.50$ cells $/ \mathrm{uL}$ in $2^{\text {nd }}$ trimester to $948.58 \pm 38.86 \mathrm{cells} / \mathrm{uL}$ in $3^{\text {rd }}$ trimester (a difference of $113 \pm 2.36 \mathrm{CD} 4$ cells/uL). There was no significant increase $(\mathrm{p}>0.05)$ in TLC level from $2.93 \pm 0.15 \times 10^{9} / \mathrm{L}$ in $2^{\text {nd }}$ trimester to $3.26 \pm 0.92 \times 10^{9} / \mathrm{L}$ in $3^{\text {rd }}$ trimester among HIV seronegative pregnant women (a difference of $0.33 \pm 0.77 \times 10^{9} / \mathrm{L}$ ).

In HIV-seropositive group, there was a significant increase $(\mathrm{p}<$ 0.05 ) in CD4 cell count from $425.10 \pm 34.0$ cells/uL in second trimester to $647.05 \pm 35.77$ cells $/ \mathrm{uL}$ in $3^{\text {rd }}$ trimester (a difference of $222 \pm 1.77$ $\mathrm{CD} 4$ cells/uL). Likewise, this significant increase $(\mathrm{p}<0.05)$ was also observed in TLC from $1.97 \pm 0.10 \times 10^{9} / \mathrm{L}$ in second trimester to $2.26 \pm$ $0.76 \times 10^{9} / \mathrm{L}$ in third trimester (a difference of $0.29 \pm 0.0 \times 10^{9} / \mathrm{L}$ ).

\begin{tabular}{|c|c|c|c|c|}
\hline \multicolumn{4}{|c|}{ HIV sero-negative group results } & \multirow[b]{2}{*}{ Difference in Increase } \\
\hline Parameter & $2^{\text {nd }}$ trimester & $3^{\text {rd }}$ trimester & p-value & \\
\hline CD4 count cells/uL & $835.02 \pm 36.50$ & $948.58 \pm 38.86$ & $p<0.05$ & $113 \pm 2.36$ \\
\hline $\mathrm{TLC} \times 10^{9} / \mathrm{L}$ & $2.93 \pm 0.15$ & $3.26 \pm 0.92$ & $p>0.05$ & $0.3 \pm 0.77$ \\
\hline \multicolumn{4}{|c|}{ HIV sero- positive group result } & \\
\hline CD4 count cells/uL & $425.10 \pm 34.0$ & $647.03 \pm 35.77$ & $p<0.05$ & $222 \pm 1.77$ \\
\hline $\mathrm{TLC} \times 10^{9} / \mathrm{L}$ & $1.97 \pm 0.10$ & $2.26 \pm 0.10$ & $p<0.05$ & $0.29 \pm 0.0$ \\
\hline
\end{tabular}

Table 1: Comparative result of CD4 and TLC in second and third trimesters of women in the same HIV status.

In Table 2 below, in second trimester, there were significant higher $(\mathrm{p}<0.05)$ levels of CD4 count and TLC in sero-negative $(835.02 \pm$
36.50 cells/uL and $\left.2.93 \pm 0.15 \times 10^{9} / \mathrm{L}\right)$ than in sero-positive women $\left(425.10 \pm 34.0\right.$ cells/uL and $\left.1.97 \pm 0.10 \times 10^{9} / \mathrm{L}\right)$ respectively. 
Page 3 of 4

In third trimester, CD4 count of sero-negative $(948.58 \pm 38.86$ cells/uL) was significantly higher than $(\mathrm{p}<0.05)$ that of sero-positive women $(647.05 \pm 35.77$ cells $/ \mathrm{uL})$ but there was no significant difference $(\mathrm{p}>0.05)$ in TLC level between the sero-negative group $\left(3.26 \pm 0.92 \times 10^{9} / \mathrm{L}\right)$ and sero-positive group $\left(2.26 \pm 0.76 \times 10^{9} / \mathrm{L}\right)$.

\begin{tabular}{|l|l|l|l|}
\hline \multicolumn{5}{|c|}{ Second trimester } & p-value \\
\hline Parameter & Sero-negative & Sero-positive & $p<0.05$ \\
\hline CD4 count cells/uL & $835.02 \pm 36.50$ & $425.10 \pm 34.0$ & $p<0.05$ \\
\hline TLC $\times 10^{9} / \mathrm{L}$ & $2.93 \pm 0.15$ & $1.97 \pm 0.10$ & $p<0.05$ \\
\hline \multicolumn{5}{|l|}{ Third trimester } & $647.05 \pm 35.77$ & $p>0.05$ \\
\hline CD4 count cells/uL & $948.58 \pm 38.86$ & $2.26 \pm 0.76$ & \\
\hline TLC $\times 10^{9} / \mathrm{L}$ & $3.26 \pm 0.92$ & & \\
\hline
\end{tabular}

Table 2: Comparative result of CD4 count and TLC of HIV Sero-negative and Sero-positive pregnant women in a given trimester.

\section{Discussion}

Conventionally, TLC and CD4 are among immunologic markers used to assess the immune status of people. They are of great importance in determining the immune status of HIV patients. In this study, CD4 and TLC of non-HIV infected pregnant women increased from $2^{\text {nd }}$ trimester through 3 rd trimester but CD4 was only observed to have significant increase; TLC did not make significant increase. This indicated that pregnancy alone can influence increase in CD4 cell through $3^{\text {rd }}$ trimester. This increase might be as a result of physiological endocrine changes in pregnancy. Lieve et al. [16] noted that pregnant hormones slowdown the decline in the rate of CD4 cell count though not sustainable. It was observed that the changes in CD4 cell count which is a subset of TLC does not significantly reflect in Total lymphocyte count of the pregnant women.

HIV sero-positive pregnant women on antiretroviral drugs in this study showed that the increase in CD4 and TLC are statistically significant. This indicates that antiretroviral drugs had significant effect on the CD4 cell proliferation and this was also reflected in the increase in Total lymphocyte cell count. It has been noted that HIV suppresses body immunity as a result of depletion of CD4 cells. In the study carried out by Burn et al. [17], it was observed that HIV caused a steady decline in CD4 cell percentage during pregnancy and postpartum in HIV disease during pregnancy. In this study, HIV infected pregnant women who started antiretroviral drugs in second trimester had a progressive increase in immunologic markers, CD4 and TLC. This progressive increase indicated that antiretroviral drugs either arrested the depletion of CD4 and TLC or caused the increase in the proliferation or regeneration of CD4 and TLC among the infected pregnant women. Though the CD4 cell subtype was not determined it has been established that Highly Active Antiretroviral Therapy (HAART) halts the viral assault on CD4 progenitor cells allowing production of new T-cells.

Considering the second trimester of sero negative and seropositive pregnant women, there were significantly low levels of CD4 count and TLC of the seropositive group than the sero-negative pregnant women. This indicates that physiological changes in pregnant women do not hamper the depletion of CD4 cell by HIV. This depletion might be as a result of increased CD4 cell death in the peripheral blood or decreased production of the CD4 and TLC in these pregnant women by the HIV. It may be that the sources of production namely- the bone marrow, the thymus, and other extrathymic lymphoid tissues (e.g. lymph nodes, spleen, and mucosa) are rendered dysfunctional in HIV disease resulting in low rate of replacement in the face of continued CD4+ cell destruction.

In the $3^{\text {rd }}$ trimester of both seronegative and seropositive pregnant women, it was observed that CD4 count of seropositive pregnant women was significantly lower than that of seronegative group. Within the interval of 120 days (between $2^{\text {nd }}$ and $3^{\text {rd }}$ trimesters), initiation of antiretroviral drugs at $2^{\text {nd }}$ trimester did not raise the CD4 count of the HIV-infected pregnant women to a level corresponding with their seronegative counterparts. The difference in CD4 cell count between 3rd trimester and $2^{\text {nd }}$ trimester of each group indicated a higher regeneration or reduced depletion of $\mathrm{CD} 4$ cells in seropositive pregnant women on Antiretroviral drugs than seronegative pregnant women.

At 2nd trimester of pregnancy, there was significant difference between TLC levels of the two groups of women when compared, but no significant change in TLC when the two groups of women were compared at their third trimester. This indicates that treatment of HIV infection in pregnant women could be monitored using Total lymphocyte count in place of CD4 count in resource limited settings. Mahayan et al. [18] and Mbanya et al. [19] recommended using TLC as a surrogate marker for CD4 count after initiation of HAART but frequent estimation should be done.

In conclusion, reduction of CD4 cell count and TLC at $2^{\text {nd }}$ trimester in HIV- infected pregnant women showed that HIV infection depletes these immunologic markers in pregnancy. As administration of antiretroviral drugs from second trimester boosted the CD4 cell count and TLC among the HIV infected pregnant women before delivery, they could be used to boost the immune status of these women, and possibly prevent vertical transmission of HIV from mother to child when initiated at $2^{\text {nd }}$ trimester. Progressive increase in TLC alongside CD4 cell count among the women on ARD suggests that TLC could be used as a surrogate to monitor progress of treatment among HIVinfected pregnant women in resource limited settings.

\section{References}

1. Agboghoroma CO (2005) Management of HIV in pregnancy: a clinical review. Tropical Journal of Obstetric Gynaecology 22: 65-73.

2. Ikechebelu JI, Udigwe G, Ngozi JI (2006) Factors that influence the acceptance of HIV testing by pregnant women in Nnewi. Nigeria Tropical Journal of medical research 10: 1-5. 
Citation: $\quad$ Okeke CU, Ukibe SN, Holy B, Ezeiruaku F (2016) The Preterm Effect of Antiretroviral Drugs on Total Lymphocyte Cells and CD4 Cells in HIV-Infected Pregnant Women . J Blood Disord Transfus 7: 353. doi:10.4172/2155-9864.1000353

Page 4 of 4

3. Ekure EN, Etuk SJ (2003) Factors influencing HIV Seroprevalence rate among pregnant women in Calabar, Nigerian. Global Journal of medical Sciences 2: 91-95.

4. Garcia A, Jennifer M, Heidi N, Olufs C (2000) Treatment Issues for Women. AIDS Community Research Initiative of America: 1.

5. French R, Brocklehurst P (1998) The effect of pregnancy on survival in women infected with HIV: a systematic review of the literature and metaanalysis. Br J Obstet Gynaecol 105: 827-835.

6. Udoka OC, Nnamdi OB, Holy B, Gospel A (2015) The effects of HIV infection on pregnancy hormones within 28 weeks of pregnancy. Brunei Int Med J 11: 88-92.

7. Rich KC, Scegel JN, Jennings C, Rydman RJ, Landay AL (1995) CD 4+ Lymphyocytes in perinatal human immunodeficiency virus (HIV) infection: evidence for pregnancy - induced immune depression in infected and HIV-infected women. J Infect Dis 172: 1221-1227.

8. Wilson ME, Dimayuga FO, Reed JL, Curry TE, Anderson CF, et al. (2006) Immune modulation by estrogens: role in CNS HIV-1 infection. Endocrine 29: 289-297.

9. Brettle RP, Raab GM, Ross A, Fielding KL, Gore SM, et al. (1995) HIV infection in women: immunological markers and the influence of pregnancy. AIDS 9: 1177-1184.

10. Temmerman M, Nagelkerke N, Bwayo J, Chomba EN, Ndinya-Achola J, et al. (1995) HIV-1 and immunological changes during pregnancy: a comparison between HIV-1-seropositive and HIV-1-seronegative women in Nairobi, Kenya. AIDS 9: 1057-1060.

11. Simonart T, Van Vooren JP, Meuris S (2002) Treatment of Kaposi's sarcoma with human chorionic gonadotropin. Dermatology 204: 330-333.

12. Simonart T, Hermans P, Delogne-Desnoeck J, Van Vooren JP, Meruis S (2002) Stimulation of Kaposi's sarcoma cell growth by urine from women in early pregnancy, the current source for clinical grade human chorionic gonadotrpin preparations. Exp Dermatol 11:365- 369.

13. Lee-Huang S, Huang PL, Sun Y, Huang PL, Kung HF, et al. (1999) Lysozyme and RNases as anti-HIV components in beta-core preparations of human chorionic gonadotropin. Proc Natl Acad Sci USA 96: 2678-2681.

14. Bourinbaiar AS, Lee-Huang S (1995) Anti-HIV effect of beta subunit of human chorionic gonadotropin (beta hCG) in vitro. Immunol Lett 44: 13-18.

15. Gross S, Castilo W, Crane M, Espinosa B, Carter S, et al. (2003) Maternal serum alpha-fetor protein and human chorionic gonadotropin levels in women with human immunodeficiency virus. Am J Obstet Gynecol 188: 1052-1056.

16. Lieve VP, Shafer LA, Mayanja BN, Whiteworth JA, Grosskurth H (2007) Effect of pregnancy on HIV disease progression and survival among women in rural Uganda. Trop Med Int Health 12: 920 -928.

17. Burns DN, Nourjah P, Minkoff H, Korelitz J, Biggar RJ, et al. (1996) Changes in $\mathrm{CD} 4+$ and $\mathrm{CD} 8+$ cell levels during pregnancy and post partum in women seropositive and seronegative for human immunodeficeney virus 1. American Journal of Obstetrics and Gynaecology 174: 1461-1468.

18. Mahayan AP, Hongan Jus, Snyder B, Kumarasany N, Mehta K, et al. (2004) Changes in total lymphocyte count as surrogate for changes in CD4 count following initiation of HAART: implications for monitoring in resource -Limited settings. J Acquir Immune Defic Syndr 36: 567-575.

19. Mbanya D, Assah F, Ndembi N, Kaptue L (2007) Monitoring antiretroviral therapy in HIV/AIDS patients in resource-limited settings: CD4 counts or total lymphocyte counts. Int J Infect Dis 11: 157-160. 